Огляди літератури, оригінальні дослідження, погляд на проблему

УДК 616.37-002.2:616.13-004.6:612.123]-085:547.932

DOI 10.11603/1811-2471.2018.v0.i1.8481

\title{
ДИНАМІКА ПОКАЗНИКІВ ЛІПІДНОГО ПРОФІЛЮ У ХВОРИХ НА ХРОНІЧНИЙ ПАНКРЕАТИТ ТА АТЕРОСКЛЕРОЗ НА ФОНІ КОМПЛЕКСНОЇ ТЕРАПІЇ ІЗ ВИКОРИСТАННЯМ УРСОДЕЗОКСИХОЛЕВОЇ КИСЛОТИ
}

\author{
๑є. С. Сірчак, С. М. Опаленик \\ ДВНЗ «Ужгородський національний університет»
}

РЕЗЮМЕ. В статті описано та проведено аналіз впливу препаратів урсодезоксихолевої кислоти (УДХК) на показники ліпідограми у хворих на хронічний панкреатит в поєднанні з атеросклерозом. Метою нашої роботи було вивчити клінічну ефективність і вплив на динаміку показників ліпідограми препарату урсодезоксихолевої кислоти на фоні комплексної терапії хворих на хронічний панкреатит та атеросклероз. Доведено, що використання препаратів УДХК при комплексному лікуванні ХП та атеросклерозу сприяє зменшенню больового, диспепсичного синдромів та синдрому зовнішньосекреторної недостатності ПЗ. Також всім хворим до та після лікування нами було проведено біохімічне дослідження крові з ліпідограмою. У всіх хворих до лікування були виявлені порушення ліпідного профілю. Встановлено, що призначення препаратів УДХК в дозуванні 15 мг/кг маси тіла протягом 3 місяців $\epsilon$ ефективним у комплексній терапії хворих на ХП в поєднанні з атеросклерозом, викликаючи нормалізацію показників ліпідограми та зменшуючи прояви зовнішньосекреторної недостатності ПЗ. При цьому покращення клінічної симптоматики наставало вже наприкінці 2-3 тижнів лікування.

КлючовІ СловА: хронічний панкреатит; атеросклероз; урсодезоксихолева кислота.

Вступ. Велика медична, соціальна та економічна проблема хронічного панкреатиту (ХП) пов'язана з високою частотою захворюваності, особливо серед працездатного населення (зазвичай ХП розвивається у віці 35-50 років), та зростанням показника інвалідності даних пацієнтів (до 15 \%). Поширеність захворювання в Європі складає 25,0-26,4 випадків на 100 тис. населення [1]. За останні 30 років у цілому світі спостерігають збільшення ХП більше, ніж у 2 рази, поширення захворювань ПЗ серед дорослого населення за останні 10 років збільшилося у 3 рази, а серед підлітків - більше, ніж у 4 рази [2].

Біліарна дисфункція робить вагомий внесок у розвиток хронічного панкреатиту. За даними спеціалізованої літератури, в 35-56 \% випадків патологія жовчовивідних шляхів $є$ фактором, що призводить до загострення хронічного панкреатиту, тим самим зменшуючи частку панкреатитів алкогольної етіології [4].

В основі сучасних уявлень про цей етіологічний варіант ХП лежить гіпотеза «загальної протоки» (common channel), запропонована $€$. Opie в 1901 р., згідно з якою анатомічна близькість місць впадання жовчної і панкреатичної проток у дванадцятипалу кишку може призводити до рефлюксу жовчі в панкреатичну протоку, що спричиняє пошкодження ПЗ детергентами, які містяться в жовчі. За останні роки з'явились відомості, що для розвитку ХП необхідні патологічні зміни самої жовчі, яку назвали токсичною, або «агресивною». Саме така жовч, потрапляючи до панкреатичної протоки, і є патологічним субстратом, що підтримує запальний процес у ПЗ, призводячи до розвитку хронічного панкреатиту. Важливими факторами розвитку даного патологічного процесу $є$ також дисліпідемічні порушення, а саме атеросклероз $[2,4]$.

Дисліпопротеїнемії будь-якого генезу можуть призводити до розвитку ХП. Найчастіше ХП розвивається в пацієнтів із гіперхіломікронемією та гіпертригліцеридемією (1,4,5-йтипи гіперліпопротеїнемії за Фридериксеном). У патогенезі гіперліпідемічних панкреатитів має значення обструкція судин залози жировими часточками, жирова інфільтрація ацинарних клітин, поява великої кількості цитотоксичних ВЖК, що утворюються внаслідок інтенсивного гідролізу ТГ під впливом надлишкового виділення ліпази [5]. Саме тому однією з важливих ланок патогенетичного лікування ХП є корекція дисліпідемічних порушень.

Препарати урсодезоксихолевої кислоти (УДХК) викликають велику зацікавленість клініцистів, оскільки добре переносяться хворими та мають доведений гіпохолестеринемічний (за рахунок зниження всмоктування холестерину в кишечнику, синтезу холестерину в печінці, екскреції холестерину в жовч) та літолітичний ефекти (зниження літогенності жовчі внаслідок формування рідких кристалів з молекулами холестерину, запобігання утворенню і розчиненню холестеринових каменів) [3].

Мета роботи - вивчити клінічну ефективність і вплив на динаміку показників ліпідограми препарату урсодезоксихолевої кислоти на фоні комплексної терапії хворих на хронічний панкреатит та атеросклероз.

Матеріал і методи дослідження. Під нашим спостереженням перебували 124 хворих на ХП та атеросклероз, які отримували стаціонарне ліку- 
Огляди літератури, оригінальні дослідження, погляд на проблему

вання В гастроентерологічному та ендокринологічному відділеннях ЗОКЛ імені А. Новака м. Ужгород, а також хворі, які перебували на амбулаторно-диспансерному спостереженні у дільничного сімейного лікаря за місцем проживання.

Діагноз ХП встановлювали відповідно до марсельсько-римських критеріїв (1989р.) з доповненнями Я. С. Циммермана (1995 р.) та уточненнями MKX-10.

Дисліпідемічні порушення виявляли шляхом аналізу показників ліпідного обміну (загальний холестерин (3X), ліпопротеїди високої щільності (ЛПВЩ), ліпопротеїди низької щільності (ЛПНЩ), ліпопротеїди дуже низької щільності (ЛПдНЩ), індекс атерогенності). Показники ліпідограми визначали на автоматичному біохімічному аналізаторі ChemWell, Awareness Technology INC (США). Коефіцієнт атерогенності (КА) вираховували за формулою: КА=(загальний ХС - ЛПВЩ)/ЛПВЩ.

Хворі були поділені на дві групи: пацієнти першої групи (65 хворих), крім дієтичного харчування, замісної терапії ферментами ПЗ, дезінтоксикаційної терапії, спазмолітиків та інгібіторів протонної помпи, додатково отримували препарат УДХК (Холудексан, фірми «World Medicine»). Добову дозу підбирали індивідуально, залежно від маси тіла, з розрахунку 15 мг УДХК на 1 кг маси тіла. Термін лікування Холудексаном становив 3 місяці. Другу групу склали 59 хворих, які отримували аналогічну терапію без призначення УДХК.
Методика проведення всіх досліджень відповідала Гельсінській декларації 1975 р. та її перегляду 1983 р. Аналіз і обробку результатів обстеження хворих здійснювали за допомогою комп'ютерної програми STATISTICA 10.0 (фірми StatSoft Inc, USA) з використанням параметричних та непараметричних методів оцінки отриманих результатів.

Наукове дослідження $\epsilon$ фрагметном держбюджетної теми № 851 «Механізми формування ускладнень при захворюваннях печінки та підшлункової залози, методи їх лікування та профілактики», номер державної реєстрації: 0115U001103, що виконується на кафедрах хірургічних хвороб та пропедевтики внутрішніх хвороб медичного факультету ДВНЗ «УжНУ».

Результати й обговорення. Клінічне обстеження хворих на ХП в поєднанні з атеросклерозом проводилось в динаміці з врахуванням больового (біль у верхній частині живота, переважно у лівому підребер'ї, оперізувального характеру), диспепсичного (зниження апетиту, нудота, блювання, метеоризм) синдромів, синдрому зовнішньосекреторної недостатності ПЗ (проноси з неприємним запахом, стеаторея).

Лікування позитивно впливало на динаміку клінічних проявів усіх 124 хворих, проте у першій групі хворих ці зміни були достовірними, а клінічний ефект наступав раніше, вже після 2-3 тижня лікування (табл. 1).

Таблиця 1. Динаміка клінічної картини у хворих на ХП в поєднанні з атеросклерозом, \%

\begin{tabular}{|c|c|c|c|c|}
\hline \multirow[t]{2}{*}{ Клінічний синдром } & \multicolumn{2}{|c|}{$\begin{array}{c}1 \text { група } \\
\text { (лікування з УДХК) }\end{array}$} & \multicolumn{2}{|c|}{$\begin{array}{c}2 \text { група } \\
\text { (лікування без УДХК) }\end{array}$} \\
\hline & до лікування & після лікування & до лікування & після лікування \\
\hline Больовий & 100 & $24,6 *$ & 100 & $28,8 *$ \\
\hline \multicolumn{5}{|l|}{ Диспепсичний } \\
\hline - зниження апетиту & 84,6 & 47,7 & 76,3 & 52,5 \\
\hline - нудота & 77,0 & 36,9 & 74,6 & 35,6 \\
\hline - блювання & 89,2 & 15,4 & 83,0 & 20,3 \\
\hline - метеоризм & 55,4 & 26,2 & 50,8 & 30,5 \\
\hline \multicolumn{5}{|l|}{ Синдром ЗСН ПЗ } \\
\hline - проноси з неприємним запахом & 78,5 & 16,9 * & 74,6 & 23,7 * \\
\hline - стеаторея & 67,7 & 24,6 * & 64,4 & 30,9 \\
\hline
\end{tabular}

Примітка: * - між показниками 1 групи та 2 групи виявлена статистично достовірна різниця $(p<0,05)$.

Аналізуючи наведені вище результати ми виявили позитивний вплив проведеного комплексного лікування на клінічну симптоматику у всіх обстежених хворих. Проте прояви больового синдрому та синдрому ЗСН ПЗ мали більш виражену позитивну динаміку у пацієнтів, які в комплексному лікуванні отримували препарат УДХК.

До та після лікування всім хворим було проведено біохімічне дослідження крові з ліпідогра- мою. У таблиці 2 наведено результати ліпідограми до та після лікування.

Як видно з наведених вище показників, у всіх хворих до лікування було виявлено порушення ліпідного профілю. Після проведеного лікування у хворих 1 групи спостерігалось зниження рівня ЗХ з $(8,17 \pm 1,15)$ ммоль/л до $(6,45 \pm 0,81)$ ммоль/л; ТГ $з(3,1 \pm 0,22)$ ммоль/л до $(1,9 \pm 0,43)$ ммоль/л; лПнщ $3(4,3 \pm 0,91)$ до $(2,6 \pm 0,71)$ ммоль/л; лпднщ з $(2,2 \pm 0,77)$ ммоль/л до $(1,3 \pm 0,23)$ ммоль/л; КА 3 
Огляди літератури, оригінальні дослідження, погляд на проблему

$(4,85 \pm 0,57)$ до $(2,93 \pm 0,38)$ відповідно. Також було відмічено підвищення рівня лПВЩ 3 $(0,88 \pm 0,19)$ ммоль/л до $(0,93 \pm 0,32)$ ммоль/л. Слід зазначити, що показники ліпідограми після проведеного лікування у хворих 1 групи $\epsilon$ незначно вищими за норму або знаходяться на верхній межі норми. Проте ці значення $\epsilon$ достовірно кращими, порівняно з вихідним рівнем. Натомість, у хворих 2 групи не спостерігалося істотних змін показників ліпідограми до та після лікування.

Таблиця 2. Зміни показників ліпідного обміну у хворих на ХП

\begin{tabular}{|c|c|c|c|c|c|}
\hline \multirow{2}{*}{ Показник } & \multirow{2}{*}{ Норма } & \multicolumn{2}{|c|}{$\begin{array}{c}1 \text { група } \\
\text { (лікування з УДХК) }\end{array}$} & \multicolumn{2}{|c|}{$\begin{array}{c}2 \text { група } \\
\text { (лікування без УДХК) }\end{array}$} \\
\hline & & 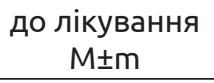 & 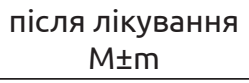 & 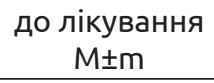 & 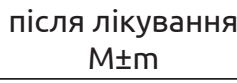 \\
\hline ТГ (ммоль/л) & $0,5-1,7$ & $3,1 \pm 0,22$ & $1,9 \pm 0,43^{*}$ & $3,0 \pm 0,21$ & $2,9 \pm 0,56$ \\
\hline 3X (ммоль/л) & $3,1-6,7$ & $8,17 \pm 1,15$ & $6,45 \pm 0,81 *$ & $8,56 \pm 1,1$ & $8,37 \pm 1,0$ \\
\hline лПНЩ (ммоль/л) & $<2,59$ & $4,3 \pm 0,91$ & $2,6 \pm 0,71^{*}$ & $4,1 \pm 0,99$ & $4,0 \pm 0,39$ \\
\hline $\begin{array}{l}\text { лПДНЩ } \\
\text { (ммоль/л) }\end{array}$ & $0,26-1,0$ & $2,2 \pm 0,77$ & $1,3 \pm 0,23 *$ & $2,0 \pm 0,88$ & $1,9 \pm 0,45$ \\
\hline лПВЩ (ммоль/л) & $>1,54$ & $0,88 \pm 0,19$ & $0,93 \pm 0,32$ & $0,96 \pm 0,23$ & $0,89 \pm 0,54$ \\
\hline KA & $2,0-2,5$ & $4,85 \pm 0,57$ & $2,93 \pm 0,38 *$ & $4,76 \pm 0,45$ & $4,69 \pm 0,97$ \\
\hline
\end{tabular}

Примітка. * - між показниками 1 групи до лікування та 1 групи після лікування виявлена статистично достовірна різниця (p<0,05).

Позитивну динаміку показників ліпідного профілю у хворих 1 групи можна пояснити гіпохолестеринемічним ефектом препаратів УДХК, а саме: зниженням всмоктування холестерину в кишечнику, синтезу холестерину в печінці та екскреції холестерину в жовч.

Отже, препарат УДХК у комплексній терапії хворих на ХП в поєднанні з атеросклерозом виявився ефективним, викликаючи нормалізацію показників ліпідограми, зменшуючи прояви зовнішньосекреторної недостатності ПЗ, при цьому покращення клінічної симптоматики наставало вже наприкінці 2-3 тижня лікування. Препарат УДХК добре переносився хворими, у жодного з пацієн- тів не виникало побічних реакцій, які 6 спричинили необхідність відміни препарату УДХК.

Висновки. 1. Препарат УДХК Холудексан $\epsilon$ ефективним і безпечним засобом в комплексному лікуванні хворих на ХПв поєднанні з атеросклерозом, сприяючи зменшенню больового, диспепсичного синдромів та синдрому зовнішньосекреторної недостатності П3. 2. Призначення препарату УДХК в дозуванні 15 мг/кг маси тіла протягом 3 місяців ефективно впливає на показники ліпідограми у даних хворих.

Перспективи подальших досліджень полягають у вивченні впливу препаратів УДХК на стан ліпідного обміну у хворих на ХП в поєднанні з атеросклерозом.

\section{ЛІТЕРАТУРА}

1. Бабак О. Я. Новые подходы к терапии ферментными препаратами у больных с хроническим панкреатитом / О. Я. Бабак, А.Е. Гриднев, В. М. Чернова // Сучасна гастроентерологія. - 2011. - № 2 (58). - С. 49-55.

2. Мігенько Б. О. Хронічний панкреатит та постхолецистектомічний синдром, підходи до лікування / Б. О. Мігенько // Вісник наукових досліджень. - 2015. № 3. - C. 11-14.

3. Палій І. Г. Біліарний сладж: можливості діагностики та лікування / І. Г. Палій, С. В. Заїка // Сучасна га-

строентерологія. - 2009. - № 6 (50). - С. 90-95.

4. Степанов Ю. М. Панкреатит: біліарний механізм, чинники та перебіг / Ю. М. Степанов, Н. Г. Заіченко // Запорізький медичний журнал. - 2012. - № 1 (70). C. $46-50$

5. Ферфецька К. В. Роль метаболічного синдрому в розвитку хронічного панкреатиту (огляд літератури) / К. В. Ферфецька, О. І. Федів // Буковинський медичний вісник. - 2013. - Т. 17, № 2 (66). - С. 174-178. 
Огляди літератури, оригінальні дослідження, погляд на проблему

\section{REFERENCES}

1. Babak, O.Ya., Gridnev, A.E., \& Chernova, V.M. (2011). Novye podkhody $k$ terapii fermentnymi preparatamy u bolnykh s khronicheskim pankreatitom [New approaches to therapy with enzyme preparations in patients with chronic pancreatitis]. Suchasna hastroenterolohiia - Modern Gastroenterology, 2 (58), 49-55 [in Russian].

2. Mihenko, B.O. (2015). Khronichnyi pankreatyt ta postkholetsystektomichnyi syndrom, pidkhody do likuvannia [Chronic pancreatitis and postcholecystectomy syndrome, approaches to treatment]. Visnyk naukovykh doslidzhen Journal of Scientific Researches, 3, 11-14 [in Ukrainian].

3. Palii, I.H., \& Zaika, S.V. (2009). Biliarnyi sladzh: mozhlyvosti diahnostyky ta likuvannia [Biliary sage: diag- nostic and treatment options]. Suchasna hastroenterolohiiaModern Gastroenterology, 6 (50), 90-95 [in Ukrainian].

4. Stepanov, Yu.M., \& Zaichenko, N.H. (2012). Pankreatyt: biliarnyi mekhanizm, chynnyky ta perebih [Pancreatitis: biliary mechanism, factors and flow]. Zaporizkyi medychnyi zhurnal - Zaporizhzhia Medical Journal, 1 (70), 46-50 [in Ukrainian].

5. Ferfetska, K.V., \& Fediv, O.I. (2013). Rol metabolichnoho syndromu $v$ rozvytku khronichnoho pankreatytu (ohliad literatury) [The role of metabolic syndrome in the development of chronic pancreatitis (review of literature)]. Bukovynskyi medychny visnyk - Bukovyna Medical Journal, 172 (66), 174-178v [in Ukrainian].

\title{
ДИНАМИКА ПОКАЗАТЕЛЕЙ ЛИПИДНОГО ПРОФИЛЯ У БОЛЬНЫХ ХРОНИЧЕСКИМ ПАНКРЕАТИТОМ И АТЕРОСКЛЕРОЗОМ НА ФОНЕ КОМПЛЕКСНОЙ ТЕРАПИИ С ИСПОЛЬЗОВАНИЕМ УРСОДЕЗОКСИХОЛЕВОЙ КИСЛОТЫ
}

\author{
ГВУз "Ужгородский национальный университет"
}

\author{
ОЕ. С. Сирчак, С. М. Опаленик
}

РЕЗЮМЕ. В статье описан и проведен анализ влияния препаратов урсодезоксихолевой кислоты (УДХК) на показатели липидограммы у больных хроническим панкреатитом в сочетании с атеросклерозом. Целью нашей работы было изучить клиническую эффективность и влияние на динамику показателей липидограммы препарата урсодезоксихолевой кислоты на фоне комплексной терапии больных хроническим панкреатитом и атеросклерозом. Доказано, что использование препаратов УДХК при комплексном лечении ХП и атеросклероза способствует уменьшению болевого, диспепсического синдромов и синдрома внешнесекреторной недостаточности Пж. Также всем больным до и после лечения нами было проведено биохимическое исследование крови и липидограмма. У всех больных до лечения были выявлены нарушения липидного профиля. Установлено, что назначение препаратов УДХК в дозе 15 мг/кг массы тела в течение 3 месяцев является эффективным в комплексной терапии больных ХП в сочетании с атеросклерозом, вызывая нормализацию показателей липидограммы и уменьшая проявления внешнесекреторной недостаточности ПЖ. При этом улучшение клинической симптоматики наступало уже в конце 2-3 недель лечения.

КЛЮчЕВЫЕ СЛОВА: хронический панкреатит; атеросклероз; урсодезоксихолевая кислота.

\section{DYNAMICS OF LIPID PROFILE INDICATORS IN PATIENTS WITH CHRONIC PANCREATITIS AND ATEROSCLEROSIS USING URSODEOXYCHOLIC ACID ON THE BACKGROUND OF COMPLEX THERAPY}

\author{
@E. S. Sirchak, S. M. Opalenyk
}

\section{Uzhhorod National University}

SUMMARY. Over the past 30 years the incidence of chronic pancreatitis has more than doubled, the prevalence of the disease among adult population over the past 10 years became 3 times higher, and among adolescents - more than 4 times, worldwide.

The effects of ursodeoxycholic acid on lipidogram indices in patients with combination of chronic pancreatitis and atherosclerosis were studied and discussed in this paper.

The aim of the study - to learn the clinical efficacy and influence of ursodeoxycholic acid on the dynamics of lipidogram indices on the background of complex therapy in patients with chronic pancreatitis and atherosclerosis.

Material and Methods. 124 patients with chronic pancreatitis and atherosclerosis were involved in the study. The diagnosis of chronic pancreatitis was based on complaints, anamnesis, laboratory and instrumental (ultrasound of the abdomen, coprogram) findings. Dyslipidemic disorders were detected by analyzing lipid metabolism indices.

The patients were divided into two groups: the first group (65 patients), besides dietary nutrition, substitution therapy with enzymes of software, detoxification therapy, anesthetics and proton pump inhibitors, additionally received the preparation of ursodeoxycholic acid. The second group consisted of 59 patients who received similar therapy without ursodeoxycholic acid. 
Огляди літератури, оригінальні дослідження, погляд на проблему

Results and Discussion. All patients had complains of pain in the left upper quadrant of epigastria, which was intensified after eating fatty or fried food. The dyspeptic syndrome, such as nausea, vomiting, heartburn, bloating, alternating diarrhea and constipation were observed in patients with chronic pancreatitis.

The dynamics of clinical manifestations of all 124 patients were positively influenced by treatment, but in the first group these changes were reliable, and the clinical effect occurred earlier, after 2-3 weeks of treatment.

Also, changes in lipidogram were observed. After 1 group patients treatment there was decrease in the total cholesterol from $8.17 \pm 1.15 \mathrm{mmol} / \mathrm{l}$ to $6.45 \pm 0.81 \mathrm{mmol} / \mathrm{l}$; triglycerides from $3.1 \pm 0.22 \mathrm{mmol} / \mathrm{l}$ to $1.9 \pm 0.43 \mathrm{mmol} / \mathrm{l}$; low density lipoproteins from $4.3 \pm 0.91 \mathrm{mmol} / \mathrm{l}$ to $2.6 \pm 0.71 \mathrm{mmol} / \mathrm{l}$; very low density lipoproteins from $2.2 \pm 0.77 \mathrm{mmol} / \mathrm{l}$ to $1.3 \pm$ $0.23 \mathrm{mmol} / \mathrm{l}$; the coefficient of atherogeny from $4.85 \pm 0.57$ to $2.93 \pm 0.38$, respectively.

Conclusions. 1. Ursodeoxycholic acid is effective and safe in the complex treatment of patients with combination of chronic pancreatitis and atherosclerosis. It leads to the reduction of pain, dyspeptic syndrome, and external-secretion insufficiency syndrome. 2. The purpose of the ursodeoxycholic acid in dose of $15 \mathrm{mg} / \mathrm{kg}$ body weight for 3 months is its effects on lipidogram in these patients.

KEY WORDS: chronic pancreatitis; atherosclerosis; ursodeoxycholic acid.

Отримано 18.01.2018 